СТАСЮК О.І., Д.т.н., професор,

ГОНЧАРОВА Л.Л., к.т.н., доцент,

ГОЛУБ Г.М., аспірант (Державний економіко-технологічний університет транспорту)

\title{
Методи організації мікропроцесорних архітектур захисту фідерів контактної мережі
}

Проведено аналіз сучасної проблеми мікропрочесорного захисту фідерів тягових мереж $і$ показані шляхи ідентифікації аномальних режимів електричних систем. Наведено математичні моделі для організації мікропрочесорного захисту $i$, на їх базі, запропоновані методи синтезу архітектур мікропрочесорних систем захисту тягових мереж з гнучкою логікою $i$ широкими функціональними можливостями поглибленого розпізнавання аномальних і аварійних режимів.

Ключові слова: мікропрочесорні системи захисту, математичні моделі, ідентифікація, аналіз, методи синтезу, тягові мережі, електричні системи.

\begin{abstract}
Постановка проблеми
Розв'язання проблеми комп’ютеризації процедур управління швидкоплинними технологічними процесами постачання електроенергії на тягу як основи організації енергозберігаючих технологій електроспоживання, мінімізації втрат, пов'язаних 3 аварійними режимами функціонування електричних мереж, і суттєвого покращення рівня безпеки руху, в умовах ринку електроенергії, тісно пов'язано 3 пошуком нових концептуальних підходів, принципів формування математичних моделей i методів оптимізації режимів електропостачання на основі перспективних IT- технологій. Дослідження процедур впливу результатів впровадження сучасних комп'ютерних засобів інтелектуалізації технологічних процесів електропостачання відкрив широкий спектр можливостей в цьому напрямку $[1,2$ ]. В той же час, досвід експлуатації показав, що на собівартості споживання електроенергії, економічності режиму електропостачання, надійності і якості функціонування електричних мереж залізниць суттєвий негативний вплив має фізичне та моральне старіння силового електрообладнання як тягових підстанцій, так і мереж електропостачання, що приводить до значного збільшення аварійних режимів, включаючи ряд складних аварій системного характеру i, відповідно, значним економічним втратам.
\end{abstract}

(C) О.І. Стасюк, Л.Л. Гончарова, Г.М. Голуб, 2015
Альтернативним рішенням комплексу задач, пов'язаних 3 забезпеченням надійності і якості функціонування мереж електропостачання, є розробка сучасних методів синтезу мікропроцесорних обчислювальних архітектур 3 гнучкою логікою, орієнтованих на проведення безперервного моніторингу фідерів тягових мереж електропостачання, реалізації в реальному часі багатокритеріального контролю кожного фідера тягової підстанції, а також визначення прогнозу можливих аномальних режимів функціонування та формування комплексу управляючих сигналів захисту систем електропостачання від аварій $[3,5,8]$. Враховуючи досвід впровадження i експлуатації сучасних мікропроцесорних засобів захисту тягових мереж від короткого замикання, а також ряд властивостей, таких як спроможність проводити тестування в реальному часі та можливість формування упередженого регулювання режимами згідно алгоритмів, дозволяє суттєво мінімізувати втрати від можливих аварій та значно компенсувати вплив ефекту старіння силового електричного обладнання на надійність електропостачання i, відповідно, безпеку руху [4, 6].

\begin{tabular}{l}
\hline Аналіз останніх досліджень і публікацій \\
\hline Комплекс проведених досліджень і аналіз \\
публікацій в сфері забезпечення високого рівня \\
надійності електропостачання на тягу і мінімізації \\
втрат від аварій дозволяє зробити висновок, що \\
загальновизнаним у світі $є$ напрямок, пов'язаний 3 \\
інтелектуалізацією процедур оперативного керування і \\
оптимізацією швидкоплинних технологічних процесів \\
електропостачання, а також комп’ютеризацією \\
процедур захисту мереж електропостачання [2, 5]. \\
Підтвердження цьому проявляється в тенденції
\end{tabular}


проектування сучасних засобів захисту, які базуються на застосуванні мікропроцесорної техніки. Такий підхід забезпечує створення систем захисту нового покоління практично любої складності, надійності та 3 широкими функціональними можливостями [6, 7]. Цей факт також обумовлений постійним зростанням складності керування електропостачанням на тягу i необхідністю проведення вимірювання і контролю в темпі електроспоживання, що потребувало високої ступені автоматизації процесів обчислення значень параметрів технологічних процесів, а також формування, в реальному часі, керуючих впливів захисту. На сьогоднішній день, в теорії і практиці релейного захисту, як показано в роботах [8], самим перспективним $\epsilon$ напрямок, пов'язаний 3 використанням комп'ютерних засобів і, в першу чергу, мікропроцесорів та розробкою на їх основі систем захисту, який отримав назву мікропроцесорного або програмного. Сукупність мікропроцесорів являються головним сегментом архітектури комп'ютерної системи релейного захисту. Обробка інформації в таких багатопроцесорних системах може реалізуватися одночасно як по незалежним програмам в кожному мікропроцесорі, так і по окремим участкам єдиної програми. Широкі функціональні можливості мікропроцесорного захисту заключаються в тому, що за допомогою мікропроцесорної архітектури реєструються тільки такі параметри як струм, напруга, можливо частота чи фаза. Всі інші параметри технологічного процесу електропостачання, такі як опір короткого замикання, швидкість зміни струму, стрибок струму та ін., розраховуються програмно. Відключення електричної системи чи окремих фідерів реалізується за допомогою комутаційних високовольтних вимикачів, привод яких оснащений механізмом, управляючий вплив на який формується за допомогою мікропроцесора по відповідному алгоритму. В зв'язку 3 тим, що за допомогою мікропроцесорних засобів $є$ можливість фіксувати в запам'ятовуючому пристрої доаварійні, аварійні і післяаварійні режими, то ефективність таких систем захисту значно збільшується завдяки можливості проведення аналізу роботи захисту та дослідницьких і експериментальних робіт 3 метою покращення їх функціонування.

Відокремлення нерозв'язаних раніше частин
загальної проблеми

Аналіз еволюції розвитку технічного прогресу автоматизації тягових електричних мереж залізниць дозволяє зробити висновок, що інноваційне перетворення мереж електропостачання i, відповідно, суттєве зменшення собівартості перевезень, покращення рівня безпеки руху i надійності функціонування електричних системи тісно пов'язане 3 комп'ютеризацією швидкоплинних технологічних процесів i систем оперативного керування електропостачанням [5,8]. Особливістю функціонування систем постачання електроенергії на тягу $\epsilon$ швидкоплинність електромагнітних i електромеханічні процесів при аварійних ситуаціях (аномальних режимах), в зв'язку 3 чим у диспетчерського і оперативного персоналу не завжди 3'являється можливість впливати на аварійний процес для зупинки його розвитку. Тому напрямок досліджень, пов'язаний 3 створенням інтелектуальних тягових мереж, що відкривають можливість не тільки різко підвищити ефективність мереж постачання електроенергії та мінімізувати загальні витрати, а i накопичувати нові «знання» режимів функціонування системи електропостачання на тягу, має великі перспективи $[1,2]$. Одною із головних складових комп'ютерного середовища, орієнтованого для інтелектуалізації процедур електропостачання на тягу, $\epsilon$ сегмент мікропроцесорного захисту аварійних режимів. Системи мікропроцесорного захисту являються складовою частиною інтелектуальної тягової мережі i, в той же час, володіють рядом специфічних властивостей, які виділяють їх в самостійний науково-технічний напрямок, основи якого базуються на фундаментальних положеннях теорії стаціонарних і нестаціонарних електромагнітних i електромеханічних процесів, теорії надійності, математичної логіки, електричних апаратів, електроніки i мікроелектроніки. Вони виконують функції локалізації ушкоджень, мінімізації втрат електроенергії при внезапній появі аварійного або аномального режиму, забезпечення живучості, стійкості і надійності системи електропостачання.

\section{Мета роботи}

На основі сучасних принципів єдиного інформаційного простору і синхронної інформаційної взаємодії розробити математичні моделі і методи синтезу мікропроцесорних архітектур 3 широкими функціональними можливостями та гнучкою логікою для захисту, в реальному часі, електричних тягових мереж залізниць, шляхом аналізу функціонування кожного фідера тягової підстанції, використовуючи сукупність методів перевірки і застосування багатокритеріальної оцінки правильності функціонування, а також проведення прогнозу можливих аномальних режимів, формування управляючих впливів захисту i файлів аварійної інформації для передачі на всі рівні керування електроспоживанням.

\section{Основний матеріал дослідження}

В силовому електроустаткуванні тягових підстанцій, системах електропостачання i на обладнанні споживачів можуть появляться ушкодження та різні аномальні режими, що приводять 
до коротких замикань. Короткі замикання можуть 3'являтися між фазами електричного обладнання і між фазою та землею. Поява короткого замикання може бути слідством дефекту або старіння ізоляції, обриву проводів, помилкових переключень і т. ін. Ушкодження, як правило, супроводжуються значним збільшенням струму, зниженням напруги i відхиленням частоти від номінальних значень в окремих сегментах або фідерах системи електропостачання. Підвищення струму загрожує ушкодженню обладнанню та лініям електропередач, а зниження напруги i частоти створює небезпеку порушення стійкості системи електропостачання i, відповідно, нормальної роботи споживачів. До інших аномальних режимів функціонування системи електропостачання можна також віднести перенавантаження, пов'язані 3 протіканням струму більше допустимого значення протягом тривалого часу. Ненормальні режимі і короткі замикання можуть бути причиною аварій, руйнування електричного обладнання, порушенням постачання електроенергії споживачу, а їх розвиток - стимулом появи системних аварій 3 великими матеріальними затратами. У більшості випадків, чим скоріше відключається частина електричної мережі постачання, на якій 3'явилося коротке замикання або аномальний режим, тим менш можливість появи аварії або створення умов розвитку системних аварій та руйнування силового електричного обладнання. При відключенні ушкодженого елемента електричної мережі в місці короткого замикання, припиняється проходження струму, гасне електрична дуга і відновлюється режим функціонування неушкодженого сегмента системи електропостачання. Завдяки виконанню подібних процедур, значно зменшуються розміри ушкодження устаткування, а у випадках своєчасної ідентифікації аномального режиму і спроможності засобів захисту організації гнучкого динамічного формування керуючих впливів для захисту систем електропостачання на тягу, відкривається можливість навіть запобігання ушкодженню. В зв'язку з цим, призначенням релейного захисту $\epsilon$ виявлення порушень нормальних режимів або місць короткого замикання $з$ подальшим автоматичним відключенням ділянки мережі електропостачання або силового електричного устаткування. Відключення ділянки електричної мережі реалізується високовольтним комутаційними апаратами, привід яких включає спеціальний механізм, на який системою захисту формується керуючий вплив. Тому пристрої автоматики, що приречені для виявлення аномальних і аварійних режимів, а також формування керуючих впливів на механізми комутаційних апаратів, відносяться до класу релейного захисту.

В той же час постійне зростання складності тягових мереж i систем керування ними та необхідність створення енергозберігаючих технологій оптимізації процесів електроспоживання в умовах ринку сформували проблему інноваційного перетворення електричних мереж, тісно пов'язаного 3 комп'ютеризацією швидкоплинних технологічних процесів електропостачання і як головною метою створення інтелектуальних електричних тягових мереж залізниць[2, 8]. Тому перспективним напрямком створення сучасної теорії i практики захисту інтелектуальних електричних мереж є розробка систем мікропроцесорного захисту нового покоління, що дозволяють динамічне формування управляючих впливів 3 необхідною селективністю, в залежності від сегменту електричної мережі, реалізувати захист практично любої складності завдяки широкій можливості логічної обробки інформації згідно алгоритмів, забезпечити високий рівень надійності 3 широкими функціональними можливостями. Завдяки застосуванню мікропроцесорів, з метою розпізнавання режиму функціонування електричної мережі, відкривається можливість виділення, в реальному часі, основної гармоніки вхідного сигналу, а для глибокої достовірності розпізнавання і організації спеціального захисту - виділення, наприклад, симетричних або інших аварійних складових. I, накінець, застосування мікропроцесорних обчислювальних архітектур відкриває можливість реалізувати ковзкий моніторинг не тільки режимів функціонування тягових мереж, а i високовольтних комутаційних апаратів та проводити, в реальному часі, їх діагностику, включаючи прогноз ресурсу. Відмітимо, що для організації надійності відключення ділянок аварійних режимів, мікропроцесорний захист вимірює тільки ряд необхідних параметрів таких як струм i, напруга u, частота $f$ і сукупність дискретних сигналів $d$, що відображають стан системи електропостачання. Сукупність інших параметрів, наприклад: швидкість зміни струму, опір режиму в момент короткого замикання, стрибок струму і т. ін., в мікропроцесорній архітектурі обчислюється в реальному часі за допомогою відповідних програм. При організації одночасного моніторингу режимів тягових мереж i високовольтних комутаційних апаратів та реалізації в реальному часі сукупності обчислювальних процедур значення технічного стану i прогнозу ресурсу, проводиться реєстрація за допомогою датчиків, набору сигналів, пов'язаних 3 визначенням тиску газу Р високовольтних вимикачів, температури $\mathrm{t}$, проміжків часу $\tau$, концентрації газу $\mathrm{H}_{2}, \mathrm{CH}_{4}, \mathrm{C}_{2} \mathrm{H}_{2}, \mathrm{C}_{2} \mathrm{H}_{6}, \mathrm{CO}, \mathrm{CO}_{2}$ в середовищі мастила як комутаційних апаратів, так і силових трансформаторів, і ряд інших інформаційних сигналів, сукупність яких позначимо як ф. Загальна сукупність первинної інформації, що відображає режим функціонування електричної мережі, може бути представлена наступним чином: 
$i_{k l}=F_{k i}\left(i_{k l}^{u}, i_{k l}^{u}, \tau, t, S_{k l}^{i} C_{k l}^{i}\right)$

$u_{k l}=F_{k l}\left(u_{k l}^{n}, u_{k l}^{a}, l, l, S_{k l}^{u} C_{k l}^{u}\right)$

$d_{k l}=F_{k l}\left(d_{k l}^{n}, d_{k l}^{a}, \tau, t, s_{k !}^{d} x_{k l}^{d}\right)$

$\varphi_{k i}=F_{k l}\left(\varphi_{k l}^{n}, \varphi_{k l}^{a}, \tau, i, S_{k l}^{q} x_{k l}^{\varphi}\right)$

$k=1,2, z, \quad l-1,2 \ldots n$.

де $\mathrm{i}_{\mathrm{kl}}^{\mathrm{n}}, \mathrm{u}_{\mathrm{kl}}^{\mathrm{n}}, \mathrm{d}_{\mathrm{kl}}^{\mathrm{n}}, \varphi_{\mathrm{lkl}}^{\mathrm{n}}$ - сигнали нормального режиму; $\mathrm{i}_{\mathrm{kl}}^{z}, \mathrm{u}_{\mathrm{k}}^{\mathrm{a}}, \mathbf{d}_{\mathrm{kl}}^{\mathrm{a}}, \varphi_{\mathrm{kl}}^{z}$ - сигнали аварійного режиму;

$\mathrm{S}_{\mathrm{kl}}^{\mathrm{i}}, \mathrm{S}_{\mathrm{kl}}^{\mathrm{u}}, \mathrm{S}_{\mathrm{kl}}^{\mathrm{d}}, \mathrm{S}_{\mathrm{k} 1}^{\varphi}$ - параметри, що визначають синхронність реєстрації інформації;

$\mathrm{C}_{\mathrm{kl}}^{\mathrm{i}}, \mathrm{C}_{\mathrm{kj}}^{\mathrm{u}}, \mathrm{C}_{\mathrm{kl}}^{\mathrm{d}}, \mathrm{C}_{\mathrm{k}]}^{\varphi}-$ набір параметрів організації єдиного інформаційного простору первинних даних;

$z$ - число фідерів $m$-го сегмента мережі електропостачання;

$\mathrm{T}$ - період частоти живлення.

На основі моделі (1) можна реалізувати формування множини керуючих впливів $\Delta_{11} \Delta_{21} \ldots \Delta_{\mathrm{zl}}$ на високовольтні комутаційні механізми системи захисту згідно узагальненої математичної залежності

$$
\Delta_{\mathrm{kl}}=\Psi_{\mathrm{kl}}^{\mathrm{V}}\left(\mathrm{i}_{\mathrm{kl}}, \mathrm{u}_{\mathrm{kk}}, \mathrm{d}_{\mathrm{kl}} \varphi_{\mathrm{ki}} \mathrm{h}_{\mathrm{kl}}\right), v=1,2, \ldots
$$

де $\Psi_{k l}{ }^{l}, \Psi_{k l}^{2}, \Psi_{k l}{ }^{3}, \ldots-$ - функції, які формують алгоритми управління;

$h_{k l}$ - параметри, що враховують топологічні особливості системи електропостачання.

Узагальнена модель проведення самоконтролю і прогнозу технічного стану високовольтних комутаційних апаратів може бути записана наступним виразом:

$$
Q_{k l}=\mathrm{G}_{\mathrm{kl}}^{\mathrm{v}}\left(\mathrm{i}_{\mathrm{kl}}, \mathrm{u}_{\mathrm{lk}}, \mathrm{d}_{\mathrm{kl}} \varphi_{\mathrm{kl}}, \Delta_{\mathrm{kl} l}, \mathrm{t}, \mathrm{\tau}, \mathrm{P}_{\mathrm{kl}}\right)
$$

де $G_{k l}{ }^{v}$ - функції, що характеризують зовнішні прояви властивостей високовольтних комутаційних апаратів.

Сукупність допустимих значень $\Delta_{k l}, d_{k l}, G_{k l}, \varphi, i$, $u$, згідно (1) - (3), можна інтерпретувати як багатовимірний простір, у межах якого може бути синтезована мікропроцесорна системи захисту тягових мереж. Домінуючою задачею при цьому є організація ковзкого моніторингу параметрів режимів систем електропостачання $\mathrm{i}$ високовольтних комутаційних апаратів, який планується проводити наступним чином. Завдяки організації первинної інформації, згідно (1) - (3), процес організації безперервного ковзкого моніторингу може бути реалізований наступним чином. Первинна інформація у вигляді аналогових, дискретних та інших сигналів за $r$ періодів $T$ частоти живлення переводиться в цифровий еквівалент і записується в пам'ять мікропроцесорної системи. Сигнали за наступний $(r+1)$-й період записується в запам'ятовуючий пристрій на місце даних першого періода, за $(r+2)$-й період $T$ відповідно на місце другого періода, і так процес продовжується циклічно до появи аномального режиму системи електропостачання. При появи аварії, в мікропроцесорній системи залишається доаварійна інформація за $r$ періодів і проводиться реєстрація всіх сигналів вподовж часу $\Delta \tau$ протікання аварійного режиму. Процедура реєстрації аварії відбувається синхронно за часом і роботою виконавчих механізмів системи захисту. Отримана інформація передається на вищі рівні оперативного керування для проведення аналізу аварії, наукових досліджень 3 метою уточнення математичних моделей i алгоритмів та покращення якості функціонування мікропроцесорної системи захисту вцілому, а також для оперативного реагування для усунення неполадок.

Моделі ідентифікації аномальних режимів мереж електропостачання на тягу. Великим позитивним фактором $\epsilon$ те, що мікропроцесорні системи захисту, завдяки використанню миттєвих значень струму i напруги, дозволяють 3 високою точністю задавати відповідні уставки захисту. Струми фідерів контактної мережі суттєво змінюються навіть в нормальних режимах роботи, особливо при запуску електричного рухомого складу, повторної появи напруги і т. ін. Тому, в якості основних характеристик режимів тягової мережі для реалізації захисту в різних сегментах топології мережі електропостачання, в більшості випадків, використовують максимальний струмовий захист $I^{\phi}{ }_{\max }$ фідера, крутизну фронту наростання струму $\frac{d i}{d t}$, скачок струму $\Delta I$, значення напруги $u$, проміжки часу $\tau$. При синтезі мікропроцесорних систем захисту можна виділити два головних взаємопов'язаних напрямки: організація архітектури мікропроцесорної системи, яка відповідає технічним умовам (таким як швидкодія, надійність, зручність експлуатаціі), і розробка алгоритмів, за допомогою яких забезпечується підвищений рівень якості виконання процедур захисту та ефективність використання можливостей комп'ютерної техніки. При цьому, необхідна така апаратна і програмна організація мікропроцесорного захисту, щоб вона мала можливість, в процесі обробки даних, динамічно змінюватися 3 метою реалізації принципово нових можливостей захисту в умовах неповноти i недостовірності первинної інформації, а також 
використовувати для аналізу аварійних даних інформацію доаварійного режиму i дані, що реєструються на суміжних дільницях мережі електропостачання для забезпечення автоматичної самонастройки до об'єкту захисту. Найбільшу популярність отримав струмовий захист, для якого впливовою величиною $\epsilon$ струм, що проходить по фідерам мережі електропостачання i, якщо він перевищить раніше установлене значення, яке називається уставкою спрацювання, то включається в роботу система захисту. Розглядають максимальний струмовий захист, який може бути як основний, так i резервний, захист на основі методу струмової відсічки використовується як допоміжний при близьких коротких замиканнях, захист від мінімальної напруги, захист по опору в момент аварії, захист по швидкості наростання струму, захист по скачку струму за час його наростання, диференційний струмовий захист, дистанційний захист, що реагує на декілька параметрів як струм, напруга і кут між ними. Для забезпечення якості функціонування мікропроцесорної системи захисту, вона повинна відповідати комплексу вимогам таких як селективність (вибірковість), стійкість функціонування, надійність. Селективність системи заключається в спроможності, з заданою швидкодією, вимикати тільки ушкоджений елемент в топології мережі електропостачання. Незалежно від того, який метод захисту або їх сукупність вибрано, для організації надійності роботи тягових мереж головним $\epsilon$ обгрунтування вибору уставок спрацювання мікропроцесорних систем моніторингу i захисту. Розглянемо декілька варіантів визначення уставок системи захисту. Якщо використовується метод максимальної струмової відсічки, то зона впливу його обмежується відстанню від тягової підстанції, що враховується за допомогою коефіцієнта чутливості $\mathrm{K}_{\mathrm{u}}$ [8]. При цьому уставка захисту вибирається згідно залежності

$\mathrm{I}_{\mathrm{Hm}} \frac{\mathrm{K}_{\mathrm{s}}}{\mathrm{K}_{\mathrm{B}}} \leq \mathrm{I}_{\mathrm{mc}}^{\mathrm{y}} \leq \frac{\mathrm{I}_{\mathrm{kmin}}}{\mathrm{K}_{\mathrm{r}}}$

де $I_{\mathrm{Hm}}$ - максимальний струм нормального (робочого) режиму;

$\mathbf{I}_{\mathbf{k} \text { min }}$ - мінімальний струм короткого замикання;

$K_{\text {z }}$ - коефіцієнт запасу який може приймати значення $\mathrm{K}_{\mathrm{z}}=(1,1 \div 1,3)$;

$\mathbf{K}_{\mathbf{I}}$ - коефіцієнт чутливості обирається із умови $\mathrm{K}_{\mathrm{r}}=(1,3: 1,5)$;

$\mathrm{I}_{\mathrm{mc}}^{\mathrm{y}}-$ струм уставки максимальної струмової відсічки;

$\mathrm{K}_{3}-$ коефіцієнт обирається 3 умов: $\mathrm{K}_{\mathrm{B}}=(0,85 \leq 0,9)[8]$.
Умови спрацювання системи захисту визначаються наступними логічними умовами:

$$
\mathrm{I}_{\mathrm{K} 3}^{\phi} \geqslant \mathrm{I}_{\mathrm{mc}}^{\mathrm{y}}
$$

де $\mathbb{I}_{\mathrm{K}}^{\phi}$ - струм короткого замикання, що протікає по фідеру.

Уставка захисту для реалізації методу струмової відсічки обирається із умови

$$
\begin{aligned}
& \mathrm{I}_{\text {co }}^{\mathrm{y}} \geq \mathrm{K}_{\mathrm{OT}} \mathrm{I}_{\mathrm{K} \max }, \\
& \mathrm{I}_{\text {co }}^{\mathrm{y}} \geq \mathrm{K}_{3} \mathrm{I}_{\mathrm{H} \max },
\end{aligned}
$$

де $\mathrm{I}_{\text {co }}^{y}$ - струм уставки при використанні методу струмової відсічки;

$$
\mathrm{K}_{\mathrm{OT}}-\text { коефіцієнт настройки, } \mathrm{K}_{\mathrm{OT}}=(1,2 \div 1,6) \text {; }
$$

$\mathrm{K}_{3}$ - коефіцієнт запасу, $\mathrm{K}_{s}=(1,15 \div 1,25)$.

Крім того, струм уставки $\mathbb{I}_{\text {co }}^{y}$ перевіряється на основі коефіцієнту чутливості $\mathbf{K}_{\mathbf{2}}$ наступним чином: $\mathrm{K}_{\mathrm{r}}=\mathrm{I}_{\mathrm{kmin}} / \mathrm{I}_{\mathrm{ra}}^{\mathrm{y}}$, а умови формування захисту відповідно $\mathrm{I}_{\mathrm{K} 3}^{\phi} \geq \mathrm{I}_{\mathrm{co}}^{\mathrm{y}}$.

Реалізація захисту від мінімальної напруги також реалізується на основі формування уставки захисту $\mathrm{U}^{y}$ відповідно

$\mathrm{U}_{\mathrm{k} \max } \mathrm{K}_{\mathrm{r}} \leq \mathrm{U}^{y} \geq \frac{\mathrm{U}_{\mathrm{H} \min }}{\mathrm{K}_{\mathrm{s}}}$

де $\mathbf{U}_{\mathbf{k} \text { max }}$ - максимальна напруга на місці короткого замикання;

$\mathbf{U}_{\mathbf{H} \text { min }}$ - мінімальна напруга на місці короткого замикання. Умови формування впливів захисту для відключення фідера визначаються відповідно $\mathrm{UY} \geq \mathrm{U}_{\mathrm{KB}}$.

Метод захисту тягових мереж на основи визначення величини опору в момент короткого замикання може використовуватись як в якості основного, так i резервного. На фідерах тягових підстанцій уставка спрацювання обирається із умови

$\mathrm{R}^{\mathrm{y}} \leq \mathrm{K}_{\mathrm{OT}} \mathrm{R}_{\mathrm{K} \min }$

і перевіряється на нечутливість відповідно

$R^{y} \leq \frac{K_{1} R_{H \min }}{K_{2} K_{3}}$

де $\mathrm{R}_{\mathrm{K} \text { min }}$ - найменше значення опору петлі короткого замикання;

$\mathrm{K}_{\text {OT }}$ - коефіцієнт настройки; 

[8]

$\mathrm{K}_{1}, \mathrm{~K}_{2}, \mathrm{~K}_{3}$ обираються згідно відповідних таблиць

Ідентифікація аварійного режиму i, відповідно, формування керуючих впливів на відключення фідера реалізується як $\mathrm{R}^{y} \geq \mathrm{R}_{\mathrm{Kz}}$, де $\mathrm{R}_{\mathrm{Kz}}-$ значення опору в момент короткого замикання.

Дуже важливим показником для організації режиму штатного електропостачання $є$ такий параметр, як швидкість наростання струму $\frac{\mathrm{di}}{\mathrm{dt}}$, а також організація захисту на основі реєстрації стрибків струму $\Delta I$. Уставка захисту при цьому формується у вигляді

$\mathrm{K}_{\mathrm{K} 3} \Delta \mathrm{I}_{\mathrm{H} \max } \leq \Delta \mathrm{I}^{\mathrm{y}} \leq \mathrm{K}_{\mathrm{c}} \Delta \mathrm{I}_{\mathrm{k} \min } / \mathrm{K}_{\mathrm{r}}$,

де $\Delta \mathrm{I}_{\max }$ - найбільше прирощення струму в нормальному режимі;

$\mathrm{NI}_{\mathbf{k} \text { min }}$ - найменше прирощення струму при короткому замиканні;

$$
\begin{aligned}
& \mathrm{K}_{\mathrm{s}}=(1,1 \div 1,3) ; \\
& \mathrm{K}_{\mathrm{c}}-\text { коефіцієнт знижки, } \mathrm{K}_{\mathrm{C}}=(0,07 \div 0,08) \\
& \mathrm{K}_{\mathrm{r}}-\text { коефіцієнт чутливості. }
\end{aligned}
$$

Умови ідентифікації аварійного режиму визначаються згідно умови $\Delta \mathrm{I}^{\mathrm{y}} \geq \Delta \mathrm{L}_{\mathrm{k \Xi}}$.

Методи архітектурних рішень систем мікропроцесорного захисту. Розглянуті математичні моделі можуть бути взяті за основу організації архітектури мікропроцесорного системи захисту фідерів тягових мереж електропостачання. На рис. 1 наведена одна із можливих схемних реалізацій мікропроцесорної структури, орієнтованої на проведення, в реальному часі, ковзкого моніторингу параметрів режимів фідерів і високовольтних комутаційних апаратів, реєстрації первинної інформації доаварійного i аварійного режиму та проведення ідентифікації аномальних режимів чи короткого замикання.

На основі отриманих первинних доаварійних i аварійних даних, система захисту формує сукупність керуючих впливів, орієнтованих на нівелювання аномального режиму, а при появі аварійного процесу відключення уражених елементів тягової мережі. Мікропроцесорною системою захисту, при появі аварії, формуються файли аварійних даних i, відповідно, передаються в диспетчерський центр для аналізу і оперативного керування.

Після запуску мікропроцесорної системи захисту фідерів електричних тягових мереж залізниць, вона працює постійно згідно алгоритму (рис. 2) в реальному часі.
3 самого початку проводиться інсталяція мікропроцесорної системи, вводиться значення уставок по максимальному струму відсічки $\mathrm{S}_{1 \mathrm{j}}=\mathrm{I}_{\text {јмсв }}^{\mathrm{y}}$, струму відсічки $\mathrm{S}_{2 \mathrm{j}}=\mathrm{I}_{\text {јсв }}^{\mathrm{y}}$, опору короткого замикання $\mathrm{S}_{3 \mathrm{j}}=\mathrm{R}_{\mathrm{j}}^{\mathrm{y}}$, швидкості наростання струму короткого замикання $\mathrm{S}_{4 \mathrm{j}}=\frac{d i}{d t}{ }^{\mathrm{j}}$, стрибка струму $\mathrm{S}_{5 \mathrm{j}}=\Delta \mathrm{i}_{\mathrm{j}}^{\mathrm{y}}, \quad$ a також прапору $\mathrm{F}_{\mathrm{jk}}$, по кожному $j$-му фідеру. За допомогою матриці ключів $K$, реалізується реєстрація інформації по кожному $j$-му фідеру, а також суміжних фідерах, миттєвих значень струму $i_{j}$, напруги $u_{j}$, та інших параметрів, що виконується $f$ раз за період $T$ частоти живлення. В АЦП первинні дані перетворюються в цифрову форму і мікропроцесором МП проводиться обчислення дійсних значень струму $I_{d j}$, напруги $u_{d j}$, а також визначається значення опору короткого замикання $\mathrm{R}_{\mathrm{j}}$, швидкості наростання струму короткого замикання $\frac{d i}{d t}$, величину стрибка струму короткого замикання $\Delta i_{j}$ та реалізується процедура присвоєння $L_{1 j}=I_{d j}, \quad L_{2 j}=u_{d j}, L_{3 j}=R_{j}, L_{4 j}=\frac{d i}{d t} j$, $L_{5 j}=\Delta i_{j}$. Потім по кожному $j$-му фідеру реалізують послідовно $k$ логічних перевірок $L_{k j}<S_{k j}$ можливої появи аномального або аварійного режиму, за допомогою використання, відповідно, $k$-го метода $(k=1,2, \ldots, m)$ згідно (4) - (9). При виконані умови $L_{k j}<S_{k j}$, циклічний процес ковзкого моніторингу продовжується. Якщо умови $L_{k j}<S_{k j}$ не виконані, то мікропроцесором МП запускаються в заданій послідовності формувачі керуючих сигналі захисту ФКС i, за їх допомогою, якщо це можливо, аномальний режим функціонування електромережі приводиться в штатний. У випадку, коли такої можливості нема, то за допомогою ФСК реалізується відключення відповідних елементів чи сегментів системи електропостачання і проводиться аналіз на предмет кінця роботи чи подальшого продовження моніторингу. Потім мікропроцесором МП присвоюється $k$-му критерію, за допомогою якого перевіряється нормальний чи аварійний режим функціонування $j$-го фідера, значення прапору $F_{j k}=1$. Після виконання описаних процедур реалізується аналіз на предмет кінця роботи чи подальшого продовження моніторингу. Якщо кінець роботи, то виконується відповідна процедура, і мікропроцесорна система перестає працювати. При незначних рівнях аномального режиму, якщо в результаті аналізу виявилось можливим продовжувати моніторинг, то мікропроцесорна система працює аналогічно описаному в циклічному режимі. 


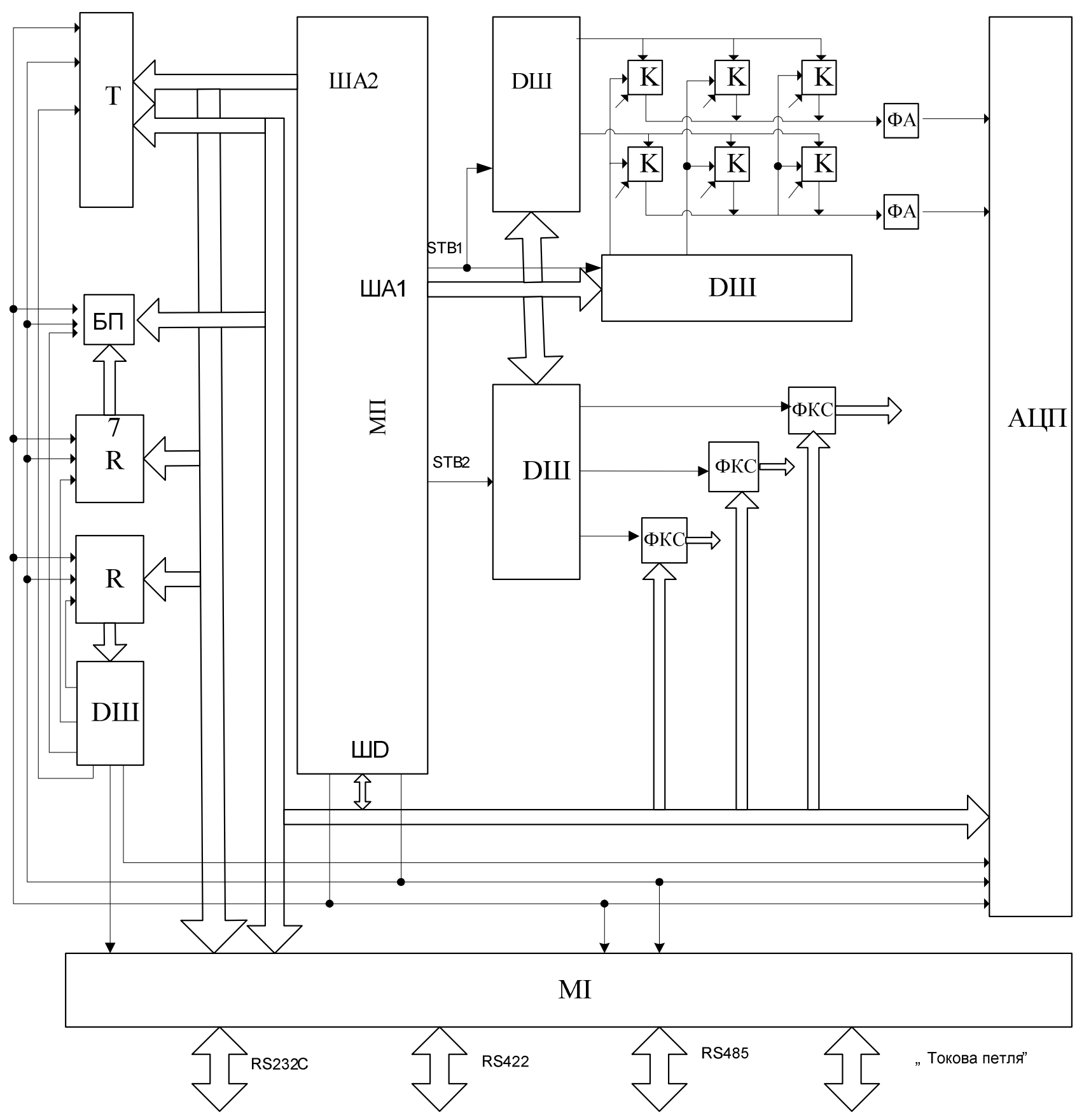

Рис. 1. Мікропроцесорна система захисту:

МП - мікропроцесор, $\mathrm{D}_{ш}$ - дешифратори,

MI - чотирьохпортовий модуль інтерфейсу, Т - таймер,

К - матриця ключів, R - регістри, АЦП - аналого - цифровий перетворювач,

ФА - формувачі аналогових сигналів,

ФКС - формувачі керуючих сигналі захисту, БП - блок пам'яті. 


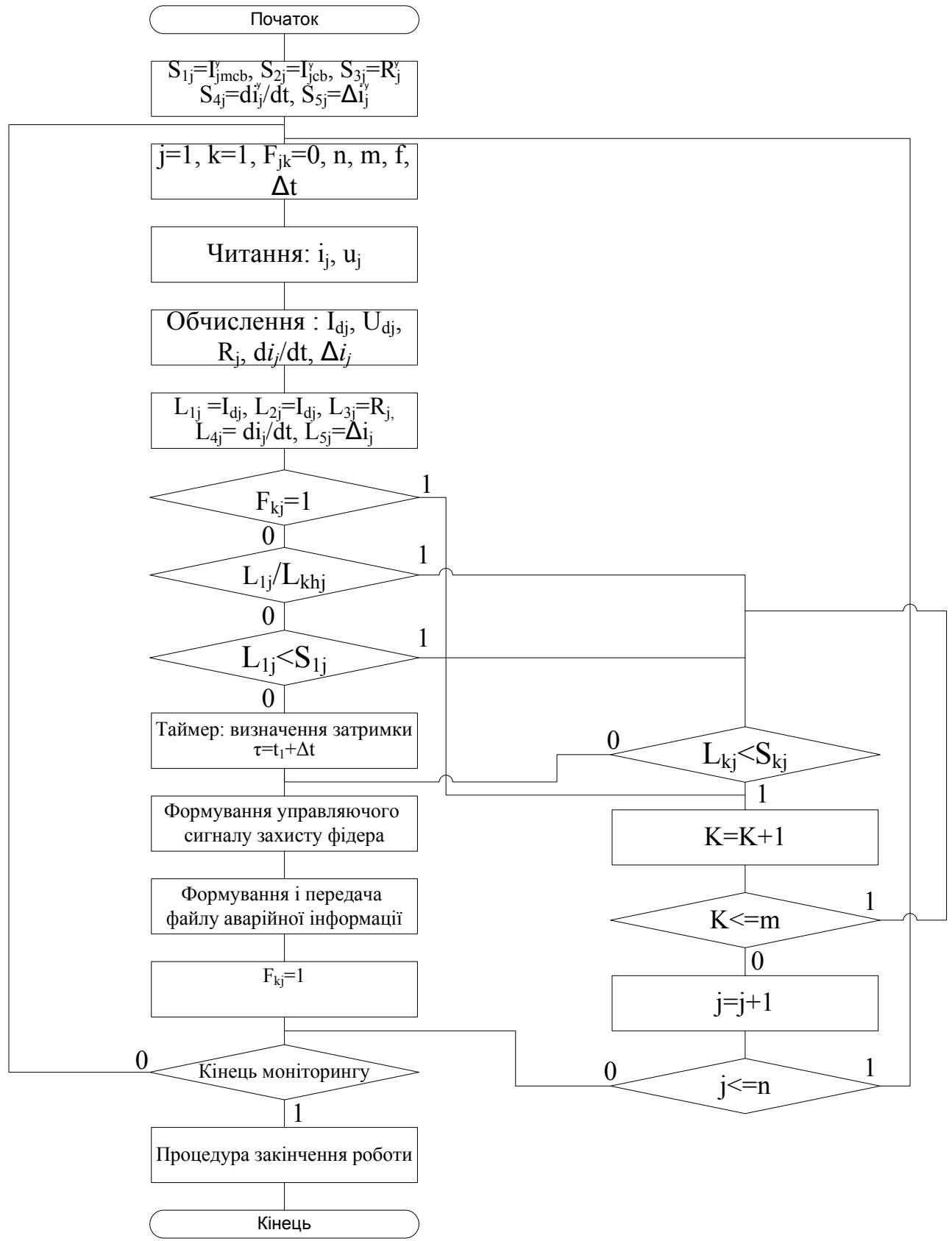

Рис. 2. Алгоритм роботи мікропроцесорної системи

\section{Висновки}

1. Проведено аналіз комплексної проблеми оптимізації технологічних процесів постачання електроенергії на тягу і дослідження еволюції розвитку технічного прогресу інтелектуалізації систем електропостачання на основі результатів яких було показано, що інноваційне перетворення мереж електропостачання тісно пов'язане 3 розв'язанням проблеми комп'ютеризації процедур ідентифікації аномальних режимів електричних систем, локалізації ушкоджень, мінімізації втрат електроенергії при внезапній появі аварійного або аномального режиму, забезпечення живучості i стійкості системи електропостачання як основи формування енергозберігаючих технологій для зменшення собівартості перевезень, покращення рівня безпеки руху та надійності функціонування тягових електричних мереж. 
2. Показано, що перспективний напрямок, пов'язаний з створенням сучасної теорії і практики захисту електричних мереж нового покоління, базується на використанні сучасних мікропроцесорних засобів, в яких завдяки спроможності логічної обробки інформації відкриваються широкі функціональні можливості реалізувати захист практично любої складності, організовувати динамічне формування керуючих впливів 3 необхідною селективністю, а для більш глибокої достовірності розпізнавання, в реальному часі аномальних режимів, забезпечити виділення симетричних або інших аварійних складових аварійного режиму.

3. Розглянуто математичні моделі як основи організації мікропроцесорного захисту, для якого впливовою величиною $є$ струм, показано методи формування уставок спрацювання для максимального струмового захисту, струмової відсічки, захисту по швидкості наростання струму, захисту по скачку струму за час його наростання та ін., показані також шляхи організації багатокритеріального захисту завдяки використанню, в процесі виконання контролю параметрів режимів кожного фідера в реальному часі, сукупності різних методів і формуванні загального висновку на основі отриманих результатів аналізу.

4. Запропоновані методи синтезу архітектур мікропроцесорних систем захисту тягових мереж 3 гнучкою логікою $\mathrm{i}$ широкими функціональними можливостями розпізнавання аномальних $\mathrm{i}$ аварійних режимів функціонування систем електропостачання, що проводиться шляхом організації ковзкого моніторингу параметрів режимів одночасно фідерів тягових мереж $\mathrm{i}$ високовольтних комутаційних апаратів, виділення в реальному часі головної i симетричних гармонік, i проводити контроль та прогноз технічного стану, включаючи запис первинної інформації доаварійного i аварійного режиму синхронно за часом та формуванням керуючих впливів захисту.

Еволюція інтелектуальних електричних мереж та їхні перспективи н в Україні // Стогній Б.С., Кириленко О.В., Праховник А.В., Денисюк С.П. ; Технічна електродинаміка 2012, №5 - С. 52-66.

2. Стасюк О.І. Методи організації інтелектуальних електричних мереж залізниць на основі концепції SMART Grid// Гончарова Л.Л., Максимчук В.Ф. Інформаційно-керуючі системи на залізничному транспорті, науково-технічний журнал, Харків 2014, № 2 -C.29-37.

3. Гончарова Л.Л. Информационные технологии мониторинга режимов электрических сетей на основе дифференциальных Т-моделей. /
Гончарова Л.Л. // Науково-технічний журнал. Інформаційно-керуючі системи на залізничному транспорті. - 2009.- № 4 - С. 93-97.

4. Стасюк О.I. Підвищення надійності моніторингу допустимості завантажень контрольованих перетинів енергосистем // Стасюк О.І., Буткевич О.Ф., Левконюк А.В. Технічна електродинаміка, Київ - 2014, №2 - С.56-67.

5. Стасюк O.I. Методи комп'ютерної інтелектуалізації режимів функціонування тягових мереж залізниць// Стасюк О.І., Гончарова Л.Л., Максимчук В.Ф., Голуб Г.М., Інформаційнокеруючі системи на залізничному транспорті, науково-технічний журнал, Харків - 2013, № 5 C. $29-36$.

6. Стасюк О.I. Методи синтезу розподілених комп'ютерно-інтегрованих мереж i технологій інтелектуалізації, моніторингу та оптимізації режимів електропостачання i енергозбереження залізниць// Стасюк O.I., Гончарова Л.Л., Максимчук В.Ф., Інформаційно-керуючі системи на залізничному транспорті, науково-технічний журнал, Харків - 2015, № 1 -С.3-10.

7. Стасюк О.I. Математичні моделі i методи організації інтелектуальних мереж постачання електроенергії на тягу залізничному транспорту// Стасюк О.I., Гончарова Л.Л., Інформаційнокеруючі системи на залізничному транспорті, науково-технічний журнал, Харків - 2015, № 3 C.10 - 19.

8. Фигурнов Е.П., Релейная защита // Фигурнов Е.П. ИПК «Желдориздат», Москва - 2002, с 720.

Стасюк А.И., Гончарова Л.Л., Голуб Г.М. Методы организации микропроцессорных архитектур защиты фидеров контактных сетей. Проведен анализ современной проблемы микропроцессорной защиты фидеров тяговых сетей, и показаны пути идентификации аномальных режимов электрических систем. Приведены математические модели для организации микропроцессорной защиты и, на их базе, предложены методы синтеза архитектур микропроцессорных систем защиты тяговых сетей, обладающих гибкой логикой и широкими функциональными возможностями углубленного распознавания аномальных и аварийных режимов.

Ключевые слова: микропроцессорные системы защиты, математические модели, идентификация, анализ, методы синтеза, тяговые сети, электрические системы. 
Stasiuk A.I., Goncharova L.L., Golub G.M. Methods of organization of microprocessor architectures for catenary system feeder protection. The analysis of the contemporary problem of traction network feeder microprocessor-based protection has been performed, and the ways to identify abnormal conditions of electric systems. Mathematical models to organize microprocessor protection have been proposed and the methods of the synthesis of microprocessor-based protection system architectures of traction networks, possessing flexible logic and broad functional capabilities of thorough recognition of abnormal conditions and malfunctions.

Key words: microprocessor-based protection systems, mathematical models, identification, analysis, synthesis methods, traction networks, electric systems.

Рецензент д.т.н., професор Тимченко Л.І. (ДЕТУТ)
Stasiuk O.I. Doctor of engineering, professor, head of department "Automation and Computer-Integrated Technologies of Transport" State Economic and Technological University of Transport, laureate of the State Prize of Ukraine, Kyiv, Ukraine.

Goncharova L. L., Ph.D., Assistant professor, department "Automation and Computer-Integrated Technologies of Transport" State Economic and Technological University of Transport, Kyiv, Ukraine.

Golub G.M., postgraduate of department "Automation and Computer-Integrated Technologies of Transport", State Economic and Technological University of Transport, Kyiv, Ukraine.

Стасюк Олександр Іонович, доктор технічних наук, професор, лауреат Державної премії в галузі науки $i$ техніки, завідувач кафедри «Автоматизаиія та комп'ютерно - інтегровані технології транспорту», Державний економіко-технологічний університет транспорту, Киї, Україна.

Поступила 10.03.20152. Гончарова Лідія Леонідівна, кандидат технічних наук, доиент кафедри «Автоматизачія та комп'ютерноінтегровані технології транспорту», Державний економіко-технологічний університет транспорту, Киів, Україна.

Голуб Галина Михайлівна, аспірант, Державний економіко-технологічний університет транспорту, Киів, Україна. 